\title{
Revisiting Exports, Imports and Economic Growth Nexus: Empirical Evidence from Bangladesh (1981-2017)
}

\author{
Md. Sazib Miyan, Md. Nurul Kabir Biplob \\ Department of Finance and Banking, Begum Rokeya University, Rangpur, Bangladesh \\ Email: sazibmiyan@brur.ac.bd,nkbiplob@brur.ac.bd
}

How to cite this paper: Miyan, Md.S. and Biplob, Md.N.K. (2019) Revisiting Exports, Imports and Economic Growth Nexus: Empirical Evidence from Bangladesh (19812017). Modern Economy, 10, 523-536. https://doi.org/10.4236/me.2019.102036

Received: January 18, 2019

Accepted: February 23, 2019

Published: February 26, 2019

Copyright (อ 2019 by author(s) and Scientific Research Publishing Inc. This work is licensed under the Creative Commons Attribution International License (CC BY 4.0).

http://creativecommons.org/licenses/by/4.0/

\section{(c) (i) Open Access}

\begin{abstract}
This study is conducted to revisit the empirical relationship between exports, imports and economic growth in Bangladesh using annual time series data from 1981 to 2017. To capture the objective, the study used Johansen Co-integration test and Granger-causality test in Vector Error Correction Model (VECM) framework. Based on the results of Johansen Co-integration test, it confirms that there is statistically significant long-run equilibrium relationship between exports, imports and economic growth. The results of the VECM Granger Causality test assure that the disequilibrium in long-run GDP growth rate is corrected or adjusted by $24 \%$ in short-run following the next year. Furthermore, the study found short-run causality running from exports to economic growth and from economic growth to imports. Finally, findings of the study will help the policy makers and development partners of Bangladesh to rethink about the current policies regarding the exports, imports, inflation, gross capital formation (investment) and economic growth.
\end{abstract}

\section{Keywords}

Economic Growth, Exports, Imports, Johansen Co-Integration test, VECM, Granger Causality, Bangladesh

\section{Introduction}

The theoretical and empirical nexus between exports, imports and economic growth has long been a subject of much interest and controversy in international trade literature because every nation wants to increase GDP and improve the quality of life for the citizen [1]. Moreover, economic growth is considered as a yardstick to measure the economic progress and development for a country. For 
this reason, different macro-economists like Mercantilists, Adam Smith and David Ricardo studied the economic policies regarding economic growth and development. Many economists believe that increase in export leads to increase in economic growth rate because export is one of the ingredients of GDP [2] [3]. Exports affect productivity and employment positively as it provides foreign exchange to finance imports that incorporate knowledge of foreign technology and production know-how, helps to concentrate of the most efficient sector where it's have comparative advantage, using economies of scale benefit and providing positive externalities on the non-export sectors. Again, import plays a significant role in the nexus between export and economic growth [4]. Many researchers found that import causes higher exports by providing higher quality intermediary goods and services [5]. That means new technologies could be embodied in imports of intermediate goods such as machines and equipments and labor productivity could increase over time that workers acquire the knowledge of the new embodied technology. As a result, many economists think exports and imports as the "Engine of Growth" for a country [6].

There are four partitions among the researchers considering the relationship among the three macro-economic variables exports, imports and economic growth [7]. One party found a positive and significant causal relationship between exports and economic growth for many countries [8]. Second party found a positive and significant relationship between imports and economic growth. Third party found a collectively casual relationship from exports and imports on economic growth, fourth party found there is no casual relationship among the three variables [9]. Some researchers also assert that the nexus depends on the type of the country and the observing period [10].

Economic growth is considered as one of the important macroeconomic indicators of welfare, changing economic structure, uplifting GDP per capita and development of a country. Bangladesh is a developing country whose current economic growth rate is more than $7 \%$ for the last 2 years [11] [12]. Bangladesh is trying to be a lower middle income country within 2021 (Vision 2021). For this reason, it needs to increase its economic growth that means per capita income. So, for policy making the respective stakeholders need to revisit these issues repeatedly.

As the macroeconomic and development conditions of the world are not same over the time, moreover it is changing in nature that's why the relationship among the macroeconomic variables are not one time solution but continuous. As the relationship is inconclusive in nature, again and again it demands investigation [13].

The objective of this research work is to econometrically revisit the nexus between exports, imports and economic growth in Bangladesh using annual time series data from 1981 to 2017 . To be more specific, this paper tried to reinvestigate empirically the relationship, whether exports lead economic growth or imports lead economic growth or economic growth leads exports and imports or 
no relationship among the three variables. The findings and recommendations of this empirical analysis will be helpful for all development partners and policy makers of Bangladesh.

This study is different from other papers by following ways: first of all, the study used long period data sets (1981-2017). Second, this paper has greater policy implications as it used more appealing and effective econometrics models such as Johansen Co-integration model and VECM. Finally, this paper used some dominant control variables namely inflation, Gross capital formation (Investment) in its model specification to isolate the true effects of exports and imports on economic growth.

The rest of the paper is organized as follows: literature review about the similar studies is given in Section 2; data and methodology of the research are discussed in Sector 3; after then, the results and analysis, as well as conclusion of the study are presented in Section 4 and 5 respectively.

\section{Literature Review}

Academicians and policy makers studied and investigated the nexus between exports, imports and economic growth again and again as the issue is very important for a country. Researchers found different result regarding the nexus among these variables. Some of them are shown below:

Bakari, S. and Mabrouks, M. [1] investigated the relationship between exports, imports and economic growth in Panama using Johansen co-integration, VAR model and Granger causality tests for annual time series data 1980-2015. They found there is no relation between exports, imports and economic growth in Panama but bidirectional causality from import to economic growth and from export to economic growth.

Mukhtar, W. L. (2017) [14] analyzed the relationship between exports and economic growth in Nigeria using Johansen co-integration and Ganger causality test within VAR model for annual time series data period 1981-2015. They found growth-led export hypothesis in long-run but export-led hypothesis in the short-run.

Gulzar, A. and Zhaohua, L. [15] studied the role of imports and its determinants in economic growth in Pakistan applying ARDL Bound test approach and found positive and significant effect of imports and its determinants in economic growth of Pakistan.

Riyath, M. and Jahfer, A. [16] examined the long run casual relationship between the exports and imports on economic growth in Sri-Lanka applying Johansen co-integration and VECM techniques for annual data 1962-2015. They showed there is no bidirectional causality but unidirectional causality between exports and economic growth.

Yuksel, S. and Zengin, S. [17] attempted to find the relationship between imports, exports and growth rate in Argentina, Brazil, China, Malaysia, Mexico and Turkey using Engle-Granger co-integration, VECM, and Toda Yamamoto anal- 
ysis for annual data 1961-2014. They found no similar result in the 6 developing countries. There is no relationship among the three variables in Brazil and Mexico but unidirectional causality relationships in Argentina where exports cause higher growth rate on other side in China and Turkey imports cause to exports again in Malaysia exports cause higher imports.

Ridzuan, A. R. and et al. [18] tried to investigate the Export-Led-Growth Hypothesis towards economic Growth of ASEAN four countries as Malaysia, Indonesia, Philippines and Thailand using Bound Test or ARDL approach for annual data 1980-2011. They empirically found that there is significant and optimistic long-run contribution towards economic growth in the ASEAN four countries.

Ucan, O. and Akyildisz, A. [19] tried to find the relationship between export and growth in the Turkey economy using co-integration and Granger causality test for annual data 2006-2015. They found unidirectional causality from export to growth but no causality from import to growth.

Saaed, A. J. and Hossain, M. A. [2] examined the causality relationship between exports, imports and economic growth in Jordan for the period of 1977-2011 using Johansen co-integration, VECM and Granger causality test. They found long-run relationship. In short-run import Granger cause GDP where the relationship is unidirectional but not vice versa.

Sachin N. Mehta [20] investigated the dynamics of the relationship between exports, imports and economic growth in India applying Johansen co-integration, VECM and Granger causality tests for the annual time series data set for 1976 to 2014. They found a long-run relationship between exports, imports and economic growth where a unidirectional causality from economic growth to exports but not export to economic growth. Moreover, exports cause imports but imports not cause exports.

Saaed, A. J. and Hossain, M. A. [3] examined the impact of exports and imports on the economic growth of Tunis using Granger causality and Johansen co-integration approach for time series data from 1977 to 2012. They found that economic growth causes imports and exports cause imports which means imports is key to economic growth in Tunisia.

Hussain, M. and Saaed, A. [21] investigated the relationship between exports, imports and economic growth in Saudi Arabia applying co-integration and Granger causality test for annual time series data period 1999-2011. They found long-run relationship among the three variables where economic growth cause import and export cause import.

Mahmood, M. et al. [22] explored the nexus between exports, imports and economic growth in Afghanistan using VECM causality model for the annual data period of 1972 to 2012. They found bidirectional causality from exports to economic growth and but no causality from economic growth and exports to imports.

Velnampy, T. and Achchuthan, S. [23] focused on the nexus of export, import and economic growth in Sri Lanka using regression analysis for the period of 
1970-2010. They found export and import have significant positive association between the variables and then ultimately effect economic growth.

Iqbal et al. [24] studied the relationship between exports and economic growth of Pakistan using Granger causality test for annual data set from 1960 to 2009. They found unidirectional causality in Pakistan from GDP to export but not vice versa.

Khan, T. F. and Kundu, N. [25] studied the future contribution of export and import to GDP in Bangladesh using Box-Jenkins approach for annual time series data set from 1981 to 2010. They found that future contribution of export in GDP will be significant.

Yuhong, L. et al. [26] investigated the relationship between foreign trade and the GDP growth of East China based on co-integration analysis, ECM and causality analysis for the period 1981-2008. They suggested there exist a long term and short term causality between total export and import and GDP but no long term causality between import and GDP.

Based on the literature review what the paper described above, one could conclude that there is a wide scope to revisit the relationship between exports, imports and economic growth. The recent statistics of international trade in Bangladesh also suggest revisiting the impacts of exports and imports on economic growth. Thus, this study attempted to investigate the nexus among the variables under consideration.

\section{Data and Methodology}

\subsection{Data and Its Origin}

This empirical study used annual time series data for all variables whether dependent or independent for the period of 1981-2017 (37 observations). The data of Gross Domestic Product (GDP) in annual growth rate, Exports (EP), Imports (IMP) and Gross Capital Formation (GCF) in percentage of GDP are collected from World Development Indicator [11] [12] published by World Bank and Inflation (INF) in percentage change in Consumer Price Index (CPI) is collected from World Economic Outlook [11] [12] published by International Monetary Fund (IMF).

Empirical studies suggest that including control variables in a model is an essential way to isolate the impact of independent variable on the dependent variable. This study considers GDP as a dependent variable; exports and imports as independent variables and inflation as well as gross capital formation as control variables. To apply empirical model and analysis all data are converted into natural logarithm form. Every estimations and diagnostic tests are carried out using Econometric views (E-views) version 10.0 statistical software.

\subsection{Model Specification and Methodology}

To examine the empirical nexus between exports, imports and economic growth an econometric model is used to link among the variables of the study. 


$$
\begin{aligned}
& \text { Economic Growth }=f(\text { Exports, Imports, Inflation, Investment }) \\
& \ln G D P_{t}=\beta_{0}+\beta_{1} \ln E P_{t}+\beta_{2} \ln I M P_{t}+\beta_{3} \ln I N F_{t}+\beta_{4} \ln G C F_{t}+\epsilon_{t} \cdots
\end{aligned}
$$

where,

$\beta_{0}=$ Constant term; $G D P=$ Gross domestic product at annual growth rate; $E P$ $=$ Exports (\% of GDP); IMP = Imports $(\%$ of $G D P) ; I N F=$ Inflation rate at percentage change in consumer price index $(C P I) ; G C F=$ Investment growth rate measured by using Gross Capital Formation; $\epsilon_{t}=$ error term assumed to be normally, identically and independently distributed, while $\beta_{1}, \beta_{2}, \beta_{3}, \beta_{4}$ are coefficients and $\ln$ indicates the natural logarithm form of variables.

Assumptions of Gauss-Markov are used in this study for testifying the validity and strength of the Ordinary Least Square (OLS). These assumptions include, model's linearity, unbiased estimation $\left(\beta_{0}, \beta_{1}, \beta_{2}, \beta_{3}, \beta_{4}\right)$ with expected value of zero i.e. $E\left(\epsilon_{t}\right)=0$ and distribution with equal variance (homoscedasticity).

The long-run and short-run relationship between exports, imports and economic growth is examined using Johansen co-integration approach and Granger causality test in Vector Error Correction Model (VECM) framework.

In co-integration analysis especially in time series data, researchers have to be conscious about the stationary of the data as there may raise a problem of spurious regression. It is well discussed issue that macroeconomic time series variables follow a random walk model that means exhibit a unit root behavior. So, to address the time series issues and related unit root test, the most popularly used techniques: The Augmented Dickey-Fuller [27] test and the Phillips-Perron [28] test have been used. All of the test will be conducted at level and first order with intercept considering the critical values of t-statistics for null hypothesis of non-stationary [29].

$\mathrm{ADF}$ and $\mathrm{PP}$ test models are as follows respectively:

$$
\begin{gathered}
\Delta Z_{t}=x+(\rho-1) Z_{t-1}+\gamma T+\delta \Delta Z_{t-1}+\varepsilon_{1 t} \\
\Delta Z_{t}=\lambda_{0}+\lambda_{1 t}+\delta Z_{t-1}+\varepsilon_{2 t}
\end{gathered}
$$

After running unit root test, if the variables are not stationary at level but stationary at first difference that is if the variable under study found stationary at same order, say in their first difference it is possible to run the regression. After running the regression, if the error terms are found stationary at level, then the linear combination of the individually non stationary variables are said to be stationary. In this case it can be said to be integrated and economically interpretable as long run relationship among the macroeconomic variables [30].

According to Utkulu [31], though the Engle-Granger co-integration test [32] is easy but it has some drawbacks that even though the estimators of long-run static regression are consistent it does not mean that they are necessarily efficient and there is no specific rule of sensible judgment about the parameters to identify variables as endogenous and exogenous.

Johansen's procedure will be applied to overcome the problems of Engle-Granger two steps procedure. Similar to the Engle-Granger approach, here 
also stationary of data will be checked. If all variables are found to be integrated stationary at the same order then the co-integrating analysis continues without suffering from spurious regression [33]. Then lag length will be selected by VAR lag order selection criteria following the democracy rule to determine the optimal lag length. After the lag length, it will identify whether the constant term or trend enters the long-run and short-run models. Finally, by Trace statistics and Maximum Eigenvalue statistics we will determine the number of co-integrating equations [34] [35] [36].

Since long-run relationships are mostly explained in static equilibrium form. For this reason it is difficult to explain the dynamics of structural and institutional changes occur in the economy within the short-run. Considering this limitation, it is necessary to study the short-run relationship and short-run dynamism of the variables under the study. The VECM is the best possible way to assess the short-run dynamic structure of the model. The Granger Representation Theorem [37] explains that if two time series variables are co-integrated then the relationship between the co-integrated variables can be expressed by a VECM model. So, after having the co-integrated long-run relationship the basic structure of VECM looks like:

$$
\begin{aligned}
\Delta L N G D P_{t}= & \mu_{11}+\sum_{i=1}^{k} \mu_{12} \Delta L N G D P_{t-i}+\sum_{i=1}^{k} \mu_{13} \Delta L N E P_{t-i}+\sum_{i=1}^{k} \mu_{14} \Delta L N I M P_{t-i} \\
& +\sum_{i=1}^{k} \mu_{15} \Delta L N I N F_{t-i}+\sum_{i=1}^{k} \mu_{16} \Delta L N G C F_{t-i}+\mu_{17} E C T_{t-1}+\epsilon_{t} \\
\Delta L N E P_{t}= & \mu_{21}+\sum_{i=1}^{k} \mu_{22} \Delta L N G D P_{t-i}+\sum_{i=1}^{k} \mu_{23} \Delta L N E P_{t-i}+\sum_{i=1}^{k} \mu_{24} \Delta L N I M P_{t-i} \\
& +\sum_{i=1}^{k} \mu_{25} \Delta L N I N F_{t-i}+\sum_{i=1}^{k} \mu_{26} \Delta L N G C F_{t-i}+\mu_{27} E C T_{t-1}+\epsilon_{t} \\
\Delta L N I M P_{t}= & \mu_{31}+\sum_{i=1}^{k} \mu_{32} \Delta L N G D P_{t-i}+\sum_{i=1}^{k} \mu_{33} \Delta L N E P_{t-i}+\sum_{i=1}^{k} \mu_{34} \Delta L N I M P_{t-i} \\
& +\sum_{i=1}^{k} \mu_{35} \Delta L N I N F_{t-i}+\sum_{i=1}^{k} \mu_{36} \Delta L N G C F_{t-i}+\mu_{37} E C T_{t-1}+\epsilon_{t} \\
\Delta L N I N F_{t}= & \mu_{41}+\sum_{i=1}^{k} \mu_{42} \Delta L N G D P_{t-i}+\sum_{i=1}^{k} \mu_{43} \Delta L N E P_{t-i}+\sum_{i=1}^{k} \mu_{44} \Delta L N I M P_{t-i} \\
& +\sum_{i=1}^{k} \mu_{45} \Delta L N I N F_{t-i}+\sum_{i=1}^{k} \mu_{46} \Delta L N G C F_{t-i}+\mu_{47} E C T_{t-1}+\epsilon_{t} \\
& +\sum_{i=1}^{k} \mu_{55} \Delta L N I N F_{t-i}+\sum_{i=1}^{k} \mu_{56} \Delta L N G C F_{t-i}+\mu_{57} E C T_{t-1}+\epsilon_{t}
\end{aligned}
$$

where, $\mu$ 's capture the short-run effects of the explanatory variables on the dependent variable, $E C T_{t-1}$ captures the rate at which the dependent variable (GDP) adjusts to the equilibrium state after structural or institutional shocks that occur.

The VECM is based on the classical linear regression model that residuals are 
normally distributed, no autocorrelation on the residuals and absence of correlation among the explanatory variables.

\section{Results and Analysis}

\subsection{Descriptive Statistics}

The descriptive statistics shown in Table 1(a) and Table 1(b) reveals the nature of all variables used in the study. The mean and median values for all variables are much close to each other depicts minor symmetry. The maximum, minimum and standard deviation row explain the dispersion of the data; here the data are not widely scattered.

Table 2 represents the correlation matrix which depicts a significant positive relationship between exports and economic growth; imports and economic growth and investment and economic growth but a negative relationship between inflation and economic growth. Left side values show lower than the right side values which is a good indication for a good fitted model. So the question of multicolinearity is not a matter of headache for this study.

\subsection{Stationary Test}

It is necessary to identify the order of integration in time series data. So, to check the stationary of the data we use Augmented Dickey-Fuller (ADF) and Phillips-Perron (PP) unit root tests and their results are shown in Table 3. The results address that all of the variables are non-stationary (has a unit root) at level but stationary at first difference i.e. integrated in order 1, I (1).

According to Table 4, the VAR lag order selection criteria suggest lag three as the optimum lag length. It is prescribed by all the techniques (LR, FPE, AIC and $\mathrm{HQ}$ ) except Schwarz information criterion (SC). So, we take lag 3 for this study for further analysis.

\subsection{Johansen Co-Integration Test}

After getting stationary of all the variables at first difference that is integrated in order 1 i.e. I (1); this study used the Johansen co-integration test to examine the long-run association between exports, imports and economic growth. In Table 5, empirical results of both the Trace test and Maximum Eigenvalue test suggest that there exist co-integration equation depicting the presence of long-run relationship among the variables. So, the null hypothesis of no co-integration is rejected considering both the tests statistics value and their respective critical value at $5 \%$ level of significance.

\subsection{Vector Error Correction Model (VECM) Granger Causality Test}

Since the Johansen co-integration test suggest the long-run relationship among the variables under the study consideration. Now it is time to observe whether there any short-run deviation exists or not from the long-run equilibrium path. This study used the VECM framework to check the disequilibrium considering 
Table 1. (a) Descriptive Statistics of all the variables (Original value); (b) Descriptive Statistics of all the variables (Natural Log form).

(a)

\begin{tabular}{cccccc}
\hline & GDP & EP & IMP & INF & GCF \\
\hline Mean & 5.103167 & 11.49278 & 17.83503 & 7.473568 & 22.18730 \\
Median & 5.121278 & 11.43115 & 16.36958 & 7.040000 & 22.72000 \\
Maximum & 7.284208 & 20.16159 & 27.94933 & 14.54500 & 30.51000 \\
Minimum & 2.134328 & 3.396255 & 11.69775 & 1.908000 & 15.47000 \\
Std. Dev. & 1.356727 & 5.154666 & 4.944116 & 3.037789 & 4.927237 \\
\hline
\end{tabular}

(b)

\begin{tabular}{cccccc}
\hline & LNGDP & LNEP & LNIMP & LNINF & LNGCF \\
\hline Mean & 28.54223 & 26.26442 & 26.78250 & 1.911709 & 3.074728 \\
Median & 28.53325 & 26.39267 & 26.73924 & 1.951608 & 3.123246 \\
Maximum & 30.61459 & 28.71987 & 29.01846 & 2.677247 & 3.418054 \\
Minimum & 26.52502 & 23.49991 & 24.56718 & 0.646056 & 2.738903 \\
Std. Dev. & 1.175922 & 1.659311 & 1.414400 & 0.486256 & 0.227572 \\
\hline
\end{tabular}

Table 2. Correlation matrix.

\begin{tabular}{cccccc}
\hline Correlation & LNGDP & LNEP & LNIMP & LNINF & LNGCF \\
\hline LNGDP & 1.000000 & & & & \\
LNEP & 0.994050 & 1.000000 & & & \\
LNIMP & 0.995451 & 0.995089 & 1.000000 & & \\
LNINF & -0.287756 & -0.309800 & -0.258423 & 1.000000 & \\
LNGCF & 0.951741 & 0.963223 & 0.962826 & -0.311092 & 1.000000 \\
\hline
\end{tabular}

Table 3. Unit root test.

\begin{tabular}{|c|c|c|c|c|c|c|c|}
\hline \multirow[b]{2}{*}{ Variables } & \multicolumn{3}{|c|}{$\mathrm{ADF}$} & \multicolumn{3}{|c|}{ PP } & \multirow[b]{2}{*}{ Remarks } \\
\hline & At level & First difference & $\begin{array}{c}\text { Lag: SIC } \\
\text { Max }\end{array}$ & At level & First difference & $\begin{array}{c}\text { Bandwidth } \\
\text { (NW) }\end{array}$ & \\
\hline LNGDP & $\begin{array}{c}0.42 \\
(0.981)\end{array}$ & $\begin{array}{c}-4.22^{\star * *} \\
(0.002)\end{array}$ & 9 & $\begin{array}{c}0.31 \\
(0.976)\end{array}$ & $\begin{array}{c}-4.19^{* * *} \\
(0.002)\end{array}$ & AS & $\mathrm{I}(1)$ \\
\hline LNEP & $\begin{array}{c}-0.73 \\
(0.826)\end{array}$ & $\begin{array}{c}-8.72^{* * *} \\
(0.000)\end{array}$ & 9 & $\begin{array}{c}-0.92 \\
(0.770)\end{array}$ & $\begin{array}{c}-9.12^{* * *} \\
(0.000)\end{array}$ & AS & $\mathrm{I}(1)$ \\
\hline LNIMP & $\begin{array}{l}-0.14 \\
(0.937)\end{array}$ & $\begin{array}{c}-5.75^{\star * *} \\
(0.000)\end{array}$ & 9 & $\begin{array}{l}-0.13 \\
(0.939)\end{array}$ & $\begin{array}{c}-5.75^{\star * *} \\
(0.000)\end{array}$ & AS & $\mathrm{I}(1)$ \\
\hline LNINF & $\begin{array}{c}-2.04 \\
(0.270)\end{array}$ & $\begin{array}{c}-7.99^{* * *} \\
(0.000)\end{array}$ & 5 & $\begin{array}{c}-3.26 \\
(0.024)\end{array}$ & $\begin{array}{c}-9.80^{* * *} \\
(0.000)\end{array}$ & AS & $\mathrm{I}(1)$ \\
\hline LNGCF & $\begin{array}{c}-0.54 \\
(0.871)\end{array}$ & $\begin{array}{c}-4.02^{* * *} \\
(0.004)\end{array}$ & 9 & $\begin{array}{c}0.19 \\
(0.968)\end{array}$ & $\begin{array}{c}-3.94^{* * *} \\
(0.005)\end{array}$ & AS & $\mathrm{I}(1)$ \\
\hline
\end{tabular}

ADF: Augmented Dickey-Fuller; PP: Phillips-Perron; NW: Newey-West; AS: Automatic Selection; ${ }^{* * *}$ indicates $1 \%$ level of significance: I (1): Integrated in $1^{\text {st }}$ order level.

the rate of convergence to the long-run equilibrium path as well as to determine the granger cause of exports and imports on economic growth and other macroeconomic variables and vice versa. 
Table 4. VAR lag order selection criteria.

\begin{tabular}{ccccccc}
\hline Lag & LogL & LR & FPE & AIC & SC & HQ \\
\hline 0 & 29.07032 & NA & $1.67 \mathrm{e}-07$ & -1.415901 & -1.191436 & -1.339352 \\
1 & 225.0904 & 322.8566 & $7.27 \mathrm{e}-12$ & -11.47590 & $-10.12912^{\star}$ & -11.01661 \\
2 & 251.7560 & 36.07697 & $7.30 \mathrm{e}-12$ & -11.57388 & -9.104767 & -10.73184 \\
3 & 293.4580 & $44.15508^{*}$ & $3.62 \mathrm{e}-12^{\star}$ & $-12.55635^{*}$ & -8.964915 & $-11.33157^{*}$ \\
\hline
\end{tabular}

*indicates lag order selected by the criterion; LR: sequential modified LR test statistic (each test at $5 \%$ level) FPE: Final prediction error; AIC: Akaike information criterion; SC: Schwarz information criterion; HQ: Hannan-Quinn information criterion.

Table 5. Johansen Co-integration test.

\begin{tabular}{|c|c|c|c|c|c|c|c|}
\hline \multirow{2}{*}{$\begin{array}{l}\text { Hypothesized } \\
\text { No. of CE(s) }\end{array}$} & \multirow[b]{2}{*}{ Eigenvalue } & \multicolumn{3}{|c|}{ Trace } & \multicolumn{3}{|c|}{ Max-Eigen } \\
\hline & & Statistic & $\begin{array}{c}0.05 \text { Critical } \\
\text { Value }\end{array}$ & Prob. ${ }^{* *}$ & Statistic & $\begin{array}{c}0.05 \text { Critical } \\
\text { Value }\end{array}$ & Prob. .* \\
\hline None ${ }^{*}$ & 0.8877 & 161.44 & 69.81 & 0.000 & 72.16 & 33.87687 & 0.0000 \\
\hline At most $1^{*}$ & 0.7745 & 89.28 & 47.85 & 0.000 & 49.15 & 27.58434 & 0.0000 \\
\hline At most $2^{*}$ & 0.5237 & 40.12 & 29.79 & 0.002 & 24.47 & 21.13162 & 0.0162 \\
\hline At most $3^{*}$ & 0.2827 & 15.64 & 15.49 & 0.047 & 10.96 & 14.26460 & 0.1558 \\
\hline At most $4^{*}$ & 0.1321 & 4.67 & 3.84 & 0.030 & 4.67 & 3.841466 & 0.0306 \\
\hline
\end{tabular}

Trace test indicates 5 co-integrating eqn(s) at the 0.05 level; Max-eigenvalue test indicates 3 cointegrating eqn(s) at the 0.05 level; ${ }^{\star}$ denotes rejection of the hypothesis at the 0.05 level; ${ }^{* *}$ MacKinnon-Haug-Michelis [29] p-values.

Table 6 shows the results of VECM where there is a stable long-run equilibrium association and short-run dynamics among the variables. The results indicate a significant long-run causality from exports and imports to economic growth. The significant and negative error correction term $(\mathrm{ECT}=-0.24)$ means that the deviation from the long-run economic growth rate in GDP is corrected by $24 \%$ by the next period which satisfy the theoretical expectation. Moreover, this study found a unidirectional causality from exports to economic growth and economic growth to imports that means in short-rum exports stimulate economic growth and GDP stimulate imports. A negative and significant coefficient of export $(-0.09)$ in short-run also supports the economic theory of J-curve. This study also found a bidirectional causality between GCF and IMP; a unidirectional causality from inflation to GDP, EP, IMP and GCF; and from GDP to GCF. This study found feedback causality in long-run between inflation and economic growth.

\subsection{Diagnostic Tests}

This study also conducted diagnostic tests for every equation shown in Table 6 and the result of the diagnostic tests reveal that all the equations are free from serial correlation and hetoroskedasticity problem and the diagnostics tests also exerts the normality of each equation at $5 \%$ level of significance. The result of 
Table 6. Vector error correction model (VECM) granger causality test [38].

\begin{tabular}{|c|c|c|c|c|c|c|}
\hline \multirow{5}{*}{ Short-run } & & $\triangle \mathrm{LNGDP}$ & $\triangle \mathrm{LNEP}$ & $\Delta$ LNIMP & $\Delta$ LNINF & $\Delta \mathrm{LNGCF}$ \\
\hline & $\triangle \mathrm{LNGDP}$ & & $\begin{array}{c}0.33 \\
(1.55)\end{array}$ & $\begin{array}{l}0.92^{* *} \\
(-2.35)\end{array}$ & $\begin{array}{c}2.02 \\
(0.58)\end{array}$ & $\begin{array}{l}0.19^{\star *} \\
(2.03)\end{array}$ \\
\hline & $\triangle$ LNEP & $\begin{array}{l}-0.09^{*} \\
(-1.71)\end{array}$ & & $\begin{array}{c}0.08 \\
(0.31)\end{array}$ & $\begin{array}{c}1.11 \\
(0.81)\end{array}$ & $\begin{array}{c}0.02 \\
(0.85)\end{array}$ \\
\hline & $\Delta$ LNIMP & $\begin{array}{l}-0.01 \\
(-0.08)\end{array}$ & $\begin{array}{l}-0.002 \\
(-0.005)\end{array}$ & & $\begin{array}{l}-1.90 \\
(-1.29)\end{array}$ & $\begin{array}{l}-0.08^{* *} \\
(-2.46)\end{array}$ \\
\hline & $\Delta$ LNINF & $\begin{array}{l}0.05^{\star *} \\
(2.55)\end{array}$ & $\begin{array}{l}0.19^{*} \\
(1.77)\end{array}$ & $\begin{array}{l}0.16^{*} \\
(1.89)\end{array}$ & & $\begin{array}{l}0.03^{* * *} \\
(4.00)\end{array}$ \\
\hline \multirow{3}{*}{ Long-run } & $\triangle$ LNGCF & $\begin{array}{c}0.13 \\
(0.33)\end{array}$ & $\begin{array}{c}1.86 \\
(0.97)\end{array}$ & $\begin{array}{l}-2.24^{*} \\
(-1.97)\end{array}$ & $\begin{array}{c}0.99 \\
(0.17)\end{array}$ & \\
\hline & ECT01(-1) & $\begin{array}{l}-0.24^{*} \\
(-1.90)\end{array}$ & $\begin{array}{l}-0.31 \\
(-0.54)\end{array}$ & $\begin{array}{l}-0.38 \\
(-0.85)\end{array}$ & $\begin{array}{l}-1.43^{*} \\
(-1.70)\end{array}$ & $\begin{array}{l}-0.25^{* * *} \\
(-4.24)\end{array}$ \\
\hline & \multicolumn{6}{|c|}{ Diagnostic Tests } \\
\hline \multicolumn{2}{|c|}{ Jarque-Bera Normality Test } & $\begin{array}{c}5.69 \\
{[0.060]}\end{array}$ & $\begin{array}{c}0.67 \\
{[0.715]}\end{array}$ & $\begin{array}{c}0.15 \\
{[0.929]}\end{array}$ & $\begin{array}{c}0.22 \\
{[0.895]}\end{array}$ & $\begin{array}{c}0.51 \\
{[0.775]}\end{array}$ \\
\hline \multicolumn{2}{|c|}{$\begin{array}{c}\text { Breusch-Godfrey Serial } \\
\text { Correlation LM Test }\end{array}$} & $\begin{array}{c}0.23 \\
{[0.873]}\end{array}$ & $\begin{array}{c}1.49 \\
{[0.264]}\end{array}$ & $\begin{array}{c}0.42 \\
{[0.743]}\end{array}$ & $\begin{array}{c}0.12 \\
{[0.949]}\end{array}$ & $\begin{array}{c}1.11 \\
{[0.382]}\end{array}$ \\
\hline \multicolumn{2}{|c|}{ ARCH Heteroskedasticity Test } & $\begin{array}{c}0.99 \\
{[0.412]}\end{array}$ & $\begin{array}{c}0.82 \\
{[0.596]}\end{array}$ & $\begin{array}{c}0.88 \\
{[0.464]}\end{array}$ & $\begin{array}{c}0.22 \\
{[0.878]}\end{array}$ & $\begin{array}{c}0.16 \\
{[0.920]}\end{array}$ \\
\hline \multicolumn{2}{|c|}{$\begin{array}{l}\text { Stability CUSUM Test and } \\
\text { CUSUM of Square Test }\end{array}$} & $\begin{array}{l}\text { Within the } \\
\text { bands }\end{array}$ & $\begin{array}{l}\text { Within the } \\
\text { bands }\end{array}$ & $\begin{array}{l}\text { Within the } \\
\text { bands }\end{array}$ & $\begin{array}{l}\text { Within the } \\
\text { bands }\end{array}$ & $\begin{array}{l}\text { Within the } \\
\text { bands }\end{array}$ \\
\hline
\end{tabular}

LM: Lagrange Multiplier; ARCH: Autoregressive Conditional Heteroscedasticity; CUSUM: Cumulative Sum; t-statistics in () and p-value in [ ]; ${ }^{* *}$ represents $1 \%,{ }^{* *}$ represents $5 \%$ and ${ }^{*}$ represents $10 \%$ level of significance respectively.

stability test considering Cumulative Sum (CUSUM) of Recursive Residuals and Cumulative Sum (CUSUM) of Squares of Recursive Residuals confirm that all the equations of VECM framework are stable in $5 \%$ level of significance.

\section{Conclusion}

The environment of international trade is changing day by day because of globalization effect. So, economists, researchers and policy makers need to revisit the relationship between exports, imports and economic growth again and again. Considering the importance, this study examines the long-run causal relationship among exports, imports and economic growth in Bangladesh using annual time series data over the period of 1981 to 2017. The stationary (has no unit root) of the data is checked using ADF and PP tests. To find the long-run association among the variables, the Johansen co-integration test is used, and to find the short-run dynamics and granger causality between variables, VECM framework is used. Johansen co-integration test finds that exports, imports and economic growth are co-integrated. VECM results demonstrate that there is a long-run equilibrium relationship among the variables and a unidirectional causality between the export and economic growth in the short run. Further, no strong evidence is found in short-run that import causes economic growth. Meanwhile, it has been found that economic growth granger causes import in short-run. Moreover, major implication of our findings is that export is matter for the economic growth of Bangladesh than import. Finally, findings of the study 
will help the policy makers and development partners of Bangladesh to rethink about the current policies regarding the exports, imports, inflation, gross capital formation (investment) and economic growth.

\section{Conflicts of Interest}

The authors declare no conflicts of interest regarding the publication of this paper.

\section{References}

[1] Bakari, S. and Mabrouks, M. (2017) Impact of Exports and Imports on Economic Growth: New Evidence from Panama. Journal of Smart Economic Growth, 1, 67-79.

[2] Saaed, A.J. and Hossain, M.A. (2015) The Causality Relationship between Exports, Imports and Economic Growth in Jordan: 1977-2012. EPRA International Journal of Economic and Business Review, 3, 11-21.

[3] Saaed, A.J. and Hossain, M.A. (2015) Impact of Exports and Imports on Economic Growth: Evidence from Tunisia. Journal of Emerging Trends in Economics and Management Sciences, 6, 13-21.

[4] Kim, S., Lim, H. and Park, D. (2009) Imports, Exports and Total Factor Productivity in Korea. Applied Economics, 41, 1819-1834. https://doi.org/10.1080/00036840601032243

[5] Bas, M. (2009) Trade, Foreign Inputs and Firms' Decisions: Theory and Evidence. CEPI1 Worlang Paper Series, 35.

[6] Medina-Smith, E.J. (2001) Is the Export-Led Growth Hypothesis Valid for Developing Countries? A Case Study of Costa Rica. Policy Issues in International Trade and Commodities Study Series No:7, UNCTAD.

[7] Dritsakis, N. (2005) Exports and Economic Growth: An Empirical Investigation of EU, USA and Japan Using Causality Tests. Department of Applied Informatics, University of Macedonia, Economics and Social Sciences.

[8] Balassa, B. (1985) Exports, Policy Choices, and Economic Growth in Developing Countries after the 1973 Oil Shock. Journal of Development Economics, 18, 23-35. https://doi.org/10.1016/0304-3878(85)90004-5

[9] Ajmi, A.N., Aye, G.C., Balcilar, M. and Gupta, R. (2015) Causality between Exports and Economic Growth in South Africa: Evidence from linear and Nonlinear Tests. The Journal of Developing Areas, 49, 163-181. https://doi.org/10.1353/jda.2015.0021

[10] Bahmani-Oskooee, M. and Economidou, C. (2009) Export Led Growth vs. Growth Led Exports: LDCs Experience. The Journal of Developing Areas, 42, 179-212. https://doi.org/10.1353/jda.0.0030

[11] WDI (2018) World Data Indicators. Published by World Bank. https://data.worldbank.org/

[12] WEO (2018) World Economic Outlook. Published by International Monetary Fund. https://data.imf.org/

[13] Sumon, K.K. and Miyan, M.S. (2017) Inflation and Economic Growth: An Empirical Evidence of Bangladesh (1986-2016). International Journal of Economics and Financial Issues, 7, 454-464.

[14] Mukhtar, W.L. (2017) Cointegration and Causality between Exports and Economic Growth: Evidence from Nigeria. Journal of Economics and Sustainable Development, 8, 91-99. 
[15] Gulzar, A. and Zhaohua, L. (2016) Analyzing the Role of Imports in Economic Growth of Pakistan; Evidence from ARDL Bound Testing Approach. International Journal of Academic Research in Business and Social Sciences, 6, 19-37.

[16] Riyath, M. and Jahfer, A. (2016) Exports, Imports and Economic Growth in Sri Lanka: Evidence from Causality and Co-integration Analysis. 5th Annual International Research Conference-2016, Faculty of Management and Commerce-SEUSL, 66-73.

[17] Yuksel, S. and Zengin, S. (2016) Causality Relationship between Import, Export and Growth Rate in Developing Countries. International Journal of Commerce and Finance, 2, 47-156.

[18] Ridzuan, A.R., et al. (2016) ASEAN4 Prospective of Export-Led Economic Growth. Journal of Business Management and Economics, 7, 1-12. https://doi.org/10.18685/EJBME(7)1_EJBME-15-018

[19] Ucan, O. and Akyildiz, A. (2016) The Relationship between Export and Economic Growth in Turkey. European Scientific Journal, 61-70.

[20] Mehta, S.N. (2015) The Dynamics of Relationship between Exports, Import and Economic Growth in India. International Journal of Research in Humanities and Social Sciences, 3, 39-47.

[21] Hussain, M. and Afaf, S. (2014) Relationship between Exports, Imports, and Economic Growth in Saudi Arabia: 1990-2011. Evidence from Co-Integration and Granger Causality Analysis. Journal of Emerging Trends in Economics and Management Sciences, 5, 364-370.

[22] Mahmood, M., et al. (2014) Exports, Imports and Economic Growth Nexus in Afghanistan. International Management Accounting Conference, 2-3 December 2014, 383-397.

[23] Achchuthan, S. (2013) Export, Import, and Economic Growth: Evidence from Sri Lanka. Journal of Economics and Sustainable Development, 4, 147-155.

[24] Iqbal, et al. (2012) Relationship between Exports and Economic Growth of Pakistan. European Journal of Social Sciences, 32, 453-460.

[25] Khan, T.F. and Kundu, N. (2012) Future Contribution of Export and Import to GDP in Bangladesh: A Box-Jenkins Approach. MPRA Paper No. 65153.

[26] Li, Y., Chen, Z. and San, C. (2010) Research on the Relationship between Foreign Trade and the GDP Growth of East China-Empirical Analysis Based on Causality. Modern Economy, 1, 118-124. https://doi.org/10.4236/me.2010.12012

[27] Dickey, D.A. and Fuller, W.A. (1981) Likelihood Ratio Statistics for Autoregressive Time Series with a Unit Root. Econometrica: Journal of the Econometric Society, 1057-1072. https://doi.org/10.2307/1912517

[28] Phillips, P.C.B. and Perron, P. (1988) Testing for a Unit Root in Time Series Regression. Biometrika, 75, 335-346. https://doi.org/10.1093/biomet/75.2.335

[29] MacKinnon, J. (1991) Critical Values for Co-Integration Tests. In: Engel, R.F. and Granger, C.W.J., Eds., Long Run Economic Relationships. Readings in Co-Integration, Oxford University Press, Oxford.

[30] Gujarati, D.N. and Porter, D.C. (2009) Basic Econometrics. 5th Edition, McGraw-Hill, Boston.

[31] Utkulu, U. (1997) How to Estimate Long-Run Relationships in Economics: An Overview of Recent Approaches. DEÜ IIBF Dergisi, 12, 39-48.

[32] Engle, R.F. and Granger, C.W. (1987) Co-Integration and Error Correction: Representation, Estimation, and Testing. Econometrica: Journal of the Econometric Society, 
55, 251-276. https://doi.org/10.2307/1913236

[33] Johansen, S. (2006) Co-Integration: A Survey. In: Mills, T.C. and Patterson, K., Eds., Palgrave Handbook of Econometrics. Volume 1, Econometric Theory, Palgrave Macmillan, New York, 17-34.

[34] Johansen, S. (1988) Statistical Analysis of Co-Integration Vectors. Journal of Economic Dynamics and Control, 12, 231-254. https://doi.org/10.1016/0165-1889(88)90041-3

[35] Johansen, S. and Juselius, K. (1990) Maximum Likelihood Estimation and Inference on Co-Integration-With Applications to the Demand for Money. Oxford Bulletin of Economics and Statistics, 52, 169-210. https://doi.org/10.1111/j.1468-0084.1990.mp52002003.x

[36] Johansen, S. (1991) Estimation and Hypothesis Testing of Co-Integration Vectors in Gaussian Vector Autoregressive Models. Econometrica, 59, 1551-1580. https://doi.org/10.2307/2938278

[37] Granger, C.W. (1969) Investigating Causal Relations by Econometric Models and Cross-Spectral Methods. Econometrica: Journal of the Econometric Society, 37, 424-438. https://doi.org/10.2307/1912791

[38] Jarque, C.M. and Bera, A.K. (1980) Efficient Tests for Normality, Homoscedasticity and Serial Independence of Regression Residuals. Economics Letters, 6, 255-259. https://doi.org/10.1016/0165-1765(80)90024-5 